\title{
Detection of haemolytic activity of campylobacters by agarose haemolysis and microplate assay
}

\author{
SUN TEE TAY, SHAMALA DEVI, SAVITHRI D. PUTHUCHEARY* and INGRID M. KAUTNER \\ Department of Medical Microbiology, Faculty of Medicine, University of Malaya, 59100 Kuala Lumpur, Malaysia
}

\begin{abstract}
Summary. There are several methods for the detection of haemolytic activity in campylobacters. However, we found the haemolytic effect of campylobacters on conventional blood agar plates to be variable, inconsistent and difficult to interpret. Blood agarose plates showed campylobacter haemolytic activity more clearly. The incubation conditions (temperature and gaseous) appear to be important for the expression of this activity. Ninety four percent of the Campylobacter isolates examined were found to be haemolytic by the microplate assay with minimal haemolytic units that ranged from 1 to 64 . Haemolytic activity was detected only from live bacterial cultures and not from any of the 50 bacterial culture supernates, which suggests that campylobacters may possess a cell-associated haemolysin. The identification of such haemolytic activity in a large number of campylobacters ( $94 \%$ ) suggests its potential role as a virulence factor in campylobacter gastroenteritis.
\end{abstract}

\section{Introduction}

Campylobacter spp. are common causes of human enteritis worldwide and are prevalent in developing countries. ${ }^{1,2}$ They rank as the third commonest cause of acute diarrhoea after rotaviruses and enterotoxigenic Escherichia coli..$^{1,3}$ Among the Campylobacter spp., $C$. jejuni and $C$. coli are isolated most frequently from human diarrhoea specimens with $C$. lari and $C$. fetus detected less often.

Despite several studies, ${ }^{4,5}$ campylobacters are generally regarded as non-haemolytic. ${ }^{6}$ The reason for this could be the lack of a sensitive method for the detection of haemolytic activity. However, haemolytic changes on blood agar plates have been observed in this study as well as in others.

The aim of this study was to investigate methods for the detection and characterisation of the haemolytic activity of Campylobacter strains isolated in Malaysia.

\section{Materials and methods}

\section{Bacterial isolates}

A total of 100 Campylobacter isolates (85 clinical and 15 animal) were used in this study. C. jejuni isolates were identified by a specific DNA probe ${ }^{7}$ (kindly provided by V. Krishnapillai, Monash Uni-

Received 4 May 1994; revised version accepted 29 Sept. 1994. * Correspondence should be sent to Dr S. D. Puthucheary. versity, Australia) and further characterised by biotyping. ${ }^{8-10}$

\section{Agarose haemolysis assay}

Briefly, agarose $1 \%$ was prepared in PBS, $\mathrm{pH} 7 \cdot 2$, and erythrocytes of various origins (human, ox, sheep or rabbit) were added to a final concentration of $2 \%$. The media were poured into petri dishes to a thickness of $1 \mathrm{~mm}$ and the agarose plates were left to dry in air.

To determine the optimal conditions for the expression of campylobacter haemolytic activity, a maximum of six bacterial cultures were inoculated in a circular manner on one blood agarose plate, and the plates were incubated for $24 \mathrm{~h}$ at two different temperatures $\left(37^{\circ} \mathrm{C}\right.$ and $\left.42^{\circ} \mathrm{C}\right)$ and in two gaseous conditions (aerobic and micro-aerophilic).

To determine quantitatively the haemolytic effect on blood agarose, holes of $1 \mathrm{~mm}$ diameter were punched into the plates. Bacterial suspensions of $10^{8}$ organisms in $10 \mu \mathrm{l}$ were pipetted into the holes. The plates were incubated aerobically at $42^{\circ} \mathrm{C}$ with bovine erythrocytes. These were found to be the optimal conditions in the preliminary experiments above.

\section{Microplate assay}

The microplate assay was performed as described by Dominguez-Rodriguez et al. ${ }^{11}$ Two-fold dilutions of bacterial suspensions were made in microtitration plates with V-bottomed wells (Linbro, USA) into which $50 \mu$ of PBS had been placed. To each bacterial 

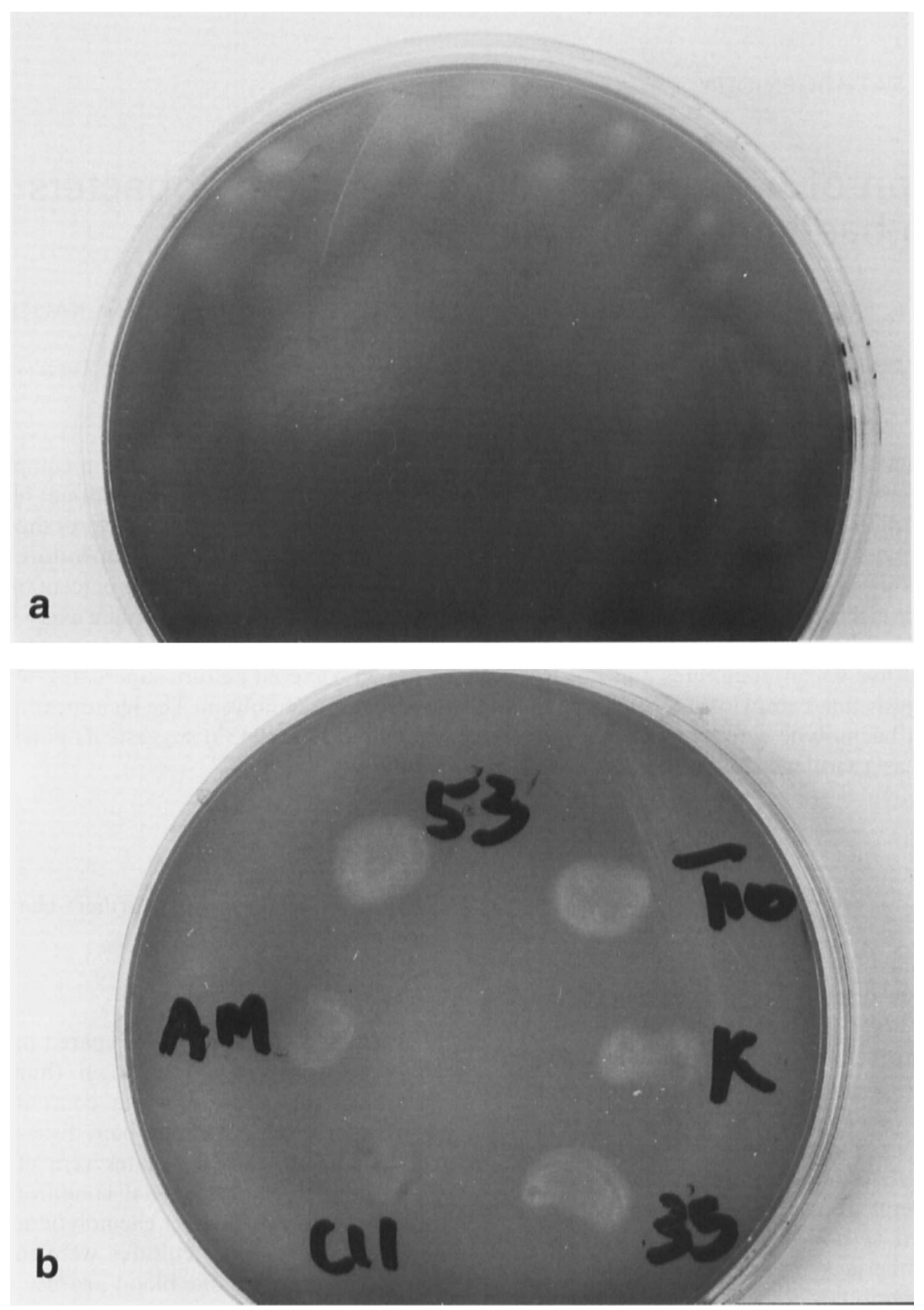

Fig. 1. a, Haemolytic activity of Campylobacter spp. on a blood agar plate. Activity is most distinct at the initial streaking site. b, clear zones due to campylobacter haemolytic activity on a blood agarose plate.

dilution, $100 \mu \mathrm{l}$ of $1 \%$ washed bovine erythrocytes were added, and the plates were incubated aerobically at $42^{\circ} \mathrm{C}$ for $18-24 \mathrm{~h}$. The haemolytic activity titre was expressed as minimal haemolytic units (MHU) which was the highest dilution at which haemolysis was detected. In both assays, sterile PBS was used as a negative control.

\section{Characterisation of haemolytic activity of campylobacters}

To determine whether the haemolysin was an extracellular product, campylobacters were cultured in three different media, each of which contained a high percentage of animal extracts, i.e., CAYE (casamino acid supplemented with yeast extract) medium, CAYE medium supplemented with fetal bovine serum $5 \%$ and Mueller Hinton broth. The bacteria (20 isolates) were grown for $48 \mathrm{~h}$ in the above media and the resulting cultures were centrifuged at $6000 \mathrm{rpm}$ for 5 min to remove most of the intact cells and cellular debris. These crude supernates were then serially diluted and the haemolytic activity was assayed by the above two methods.

\section{Polymyxin treatment}

Campylobacter isolates were suspended in PBS 
Table I. Expression of campylobacter haemolytic activity on blood agarose plates under various incubation conditions

Incubation conditions $\quad \begin{gathered}\text { Number }(/ 20) \text { of } \\ \text { haemolytic isolates }\end{gathered}$

\begin{tabular}{ll}
\hline Aerobic $42^{\circ} \mathrm{C}$ & 18 \\
Aerobic $37^{\circ} \mathrm{C}$ & 13 \\
Microaerophilic $42^{\circ} \mathrm{C}$ & 14
\end{tabular}

Note: the haemolytic activity of campylobacters incubated microaerophilically was difficult to determine. containing polymyxin B sulphate at a final concentration of $2 \mathrm{mg} / \mathrm{l}$. The suspension $\left(10^{10}\right.$ organisms $/ \mathrm{ml}$ ) was incubated at $37^{\circ} \mathrm{C}$ for $1 \mathrm{~h}$ before centrifugation at $6000 \mathrm{rpm}$ for $5 \mathrm{~min}$. The supernate was collected and the pellet was resuspended in PBS. The haemolytic activity of both polymyxin B-treated supernates and bacterial cell suspensions were determined by the agarose haemolysis and the microplate assay as described above.

\section{Haemolytic activity of bacterial lysates}

Bacterial suspensions of 10 isolates that had demonstrated haemolytic activity in the agarose haem-
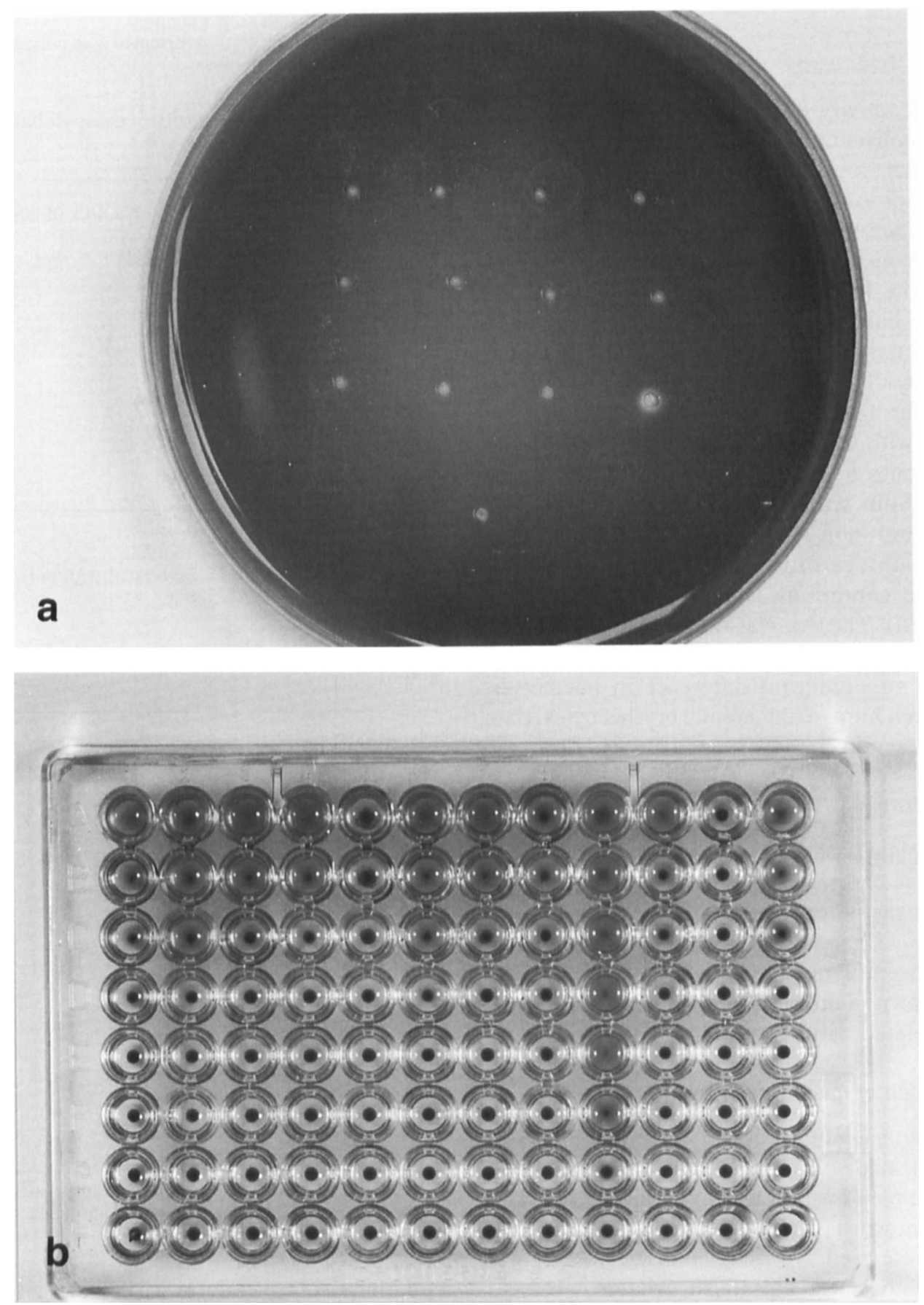

Fig. 2. a, Haemolysis of Campylobacter spp. on an ox blood agarose plate. b, microplate assay for the quantitation of campylobacter haemolytic activity. Lanes 1-10, Campylobacter test isolates; 11, negative control strain in sterile PBS; 12, haemolytic E. coli isolate. 
olysis assay were lysed by sonication (Branson Sonifier Cell Disruptor B15, USA) at $20 \mathrm{kHz}$ for $10 \mathrm{~min}$. The supernates were collected by centrifugation and assayed for haemolytic activity by the agarose haemolysis assay.

\section{Heat stability}

Bacterial suspensions of 20 isolates that had demonstrated haemolytic activity in the agarose haemolysis assay were heated at $100^{\circ} \mathrm{C}$ for $30 \mathrm{~min}$ and the remaining haemolytic activity was determined by the agarose haemolysis assay.

\section{Results}

\section{Agarose haemolysis assay}

Haemolytic activity of Campylobacter isolates was observed on conventional blood agar plates at $37^{\circ} \mathrm{C}$ and $42^{\circ} \mathrm{C}$ after incubation for $48-72 \mathrm{~h}$ in microaerophilic conditions. However, it was always necessary to scrape the colony off the agar in order to see the haemolysis. A more marked haemolytic activity was observed at the initial streaking line where a large inoculum of bacteria was normally present. The haemolytic activity of campylobacters on the agar plate was generally variable, inconsistent and difficult to interpret (fig. 1a).

However, with blood agarose plates, clear and transparent zones could be seen beneath the inoculum after $24 \mathrm{~h}$ without scraping off the colonies (fig. 1b). Haemolytic and non-haemolytic isolates could be differentiated on agarose plates. Incubation at $42^{\circ} \mathrm{C}$ under aerobic conditions enhanced the haemolytic activity (table I). The assay also allowed quantitation of haemolytic activity (fig. $2 \mathrm{a}$ and table II).

There was no significant difference in haemolytic activity between human and animal erythrocytes (data not shown).

\section{Microplate assay}

The microplate assay of Dominguez-Rodriguez et $a l .{ }^{11}$ was simple and rapid, required small amounts of reagents and was more sensitive than agarose haemolysis. It allowed haemolytic activity to be expressed in minimal haemolytic units (MHU; fig. 2b). The results are shown in table III. Haemolysin production was not correlated with biotype (table IV).

\section{Characterisation of haemolytic activity}

In this study, haemolytic activity of campylobacters was demonstrated only by intact bacterial cells. Although complex media containing animal extracts which are known to stimulate the production of haemolysin were used, ${ }^{12,13}$ no haemolytic activity was detected in the bacterial culture supernates.

Bacterial lysates of 10 Campylobacter isolates obtained after sonication and polymyxin B-treated
Table II. Haemolytic activity of campylobacters determined by the agarose haemolysis assay

\begin{tabular}{ccc}
\hline & \multicolumn{2}{c}{ Number of isolates } \\
\cline { 2 - 3 }$(\mathrm{mm})^{*}$ & Untreated $\dagger$ & $\begin{array}{c}\text { Polymyxin B- } \\
\text { treated } \$\end{array}$ \\
\hline 2 & 42 & 56 \\
3 & 25 & 32 \\
4 & 23 & 6 \\
5 & 3 & 6 \\
6 & 6 & 0 \\
7 & 1 & 0 \\
Total & 100 & 100 \\
\hline
\end{tabular}

*Haemolysis was considered positive when the zone was $\geqslant 3 \mathrm{~mm}$ in diameter.

$\dagger 10^{10}$ campylobacters $/ \mathrm{ml}$ were used.

$\ddagger 10^{10}$ campylobacters $/ \mathrm{ml}$ were treated with polymyxin $\mathrm{B} 2 \mathrm{mg} / \mathrm{ml}$ at $37^{\circ} \mathrm{C}$ for $1 \mathrm{~h}$ before the assay.

Table III. Haemolytic activity of campylobacters determined by the microplate assay

\begin{tabular}{ccc}
\hline & \multicolumn{2}{c}{ Number of isolates } \\
\cline { 2 - 3 } MHU* $^{*}$ & Untreated $\uparrow$ & Polymyxin B-treated \\
\hline 1 & 6 & 13 \\
2 & 17 & 29 \\
4 & 22 & 33 \\
8 & 35 & 20 \\
16 & 14 & 2 \\
32 & 5 & 2 \\
64 & 1 & 1 \\
Total & 100 & 100 \\
\hline
\end{tabular}

*MHU $\geqslant 2$ was considered positive.

$\dagger 10^{10}$ campylobacters $/ \mathrm{ml}$ were used.

$\ddagger 10^{10}$ campylobacters $/ \mathrm{ml}$ were treated with polymyxin B $2 \mathrm{mg} / \mathrm{ml}$ at $37^{\circ} \mathrm{C}$ for $1 \mathrm{~h}$ before the assay.

Table IV. Biotypes of campylobacters and haemolytic activity

\begin{tabular}{lcc}
\hline & $\begin{array}{c}\text { Haemolytic activity } \\
\text { (number of strains) }\end{array}$ \\
\cline { 2 - 3 } Isolates & + & - \\
& & \\
\hline Clinical & 39 & 2 \\
C. jejuni biotype I & 25 & 1 \\
C. jejuni biotype II & 10 & 1 \\
C. coli & 6 & 1 \\
Untypable isolates & 80 & 5 \\
Total & & \\
Poultry & 7 & 1 \\
C. jejuni biotype I & 4 & 0 \\
C. jejuni biotype II & 2 & 0 \\
C. coli & 1 & 0 \\
Untypable isolates & 14 & 1 \\
Total & & \\
\hline
\end{tabular}

The haemolytic activity of the bacterial suspension was determined by the microplate assay. A minimal haemolytic unit (MHU) of $\geqslant 2$ was considered as positive.

supernates of all isolates were all negative for haemolytic activity. The heat-denatured suspensions of 20 strains showed no haemolytic activity. 


\section{Discussion}

There are at present several methods for the detection of haemolytic activity. ${ }^{4,5}$ In this study, the haemolytic effect on conventional blood agar plates was variable, inconsistent and difficult to interpret, which is probably why it has not been reported for many years. Therefore, we attempted to develop a new assay for the detection of campylobacter haemolytic activity and to gain an insight into its role as a possible virulence factor of campylobacters.

In contrast to conventional blood agar plates, clear and distinct haemolytic zones were detectable on blood agarose plates (fig. 1b). The conditions of incubation (temperature and gaseous) appear to be important for the expression of this activity. Aerobic incubation at $42^{\circ} \mathrm{C}$ was optimal for the expression of this activity, since most haemolytic isolates were detected in these conditions (table I).

Haemolytic activity was not detected in the bacterial supernates of 50 isolates tested by both the agarose plate and the microplate assays suggesting that campylobacters may possess a cell-associated haemolysin. Arimi et al..$^{4}$ postulated the existence of a cell-bound haemolytic factor that is released intracellularly. However, the supernates collected after polymyxin B-treatment and the bacterial lysates obtained after sonication were also negative in this study. Furthermore, bacterial suspensions showed reduced haemolytic activity after treatment with polymyxin B. We consider that the haemolysin produced is so dilute that it could not be detected in the supernates after the destruction of the bacteria or that the intact cell was required to produce the haemolytic activity. Although the haemolysin has been reported to be thermostable and extractable by boiling in saline, ${ }^{5}$ no haemolytic activity was detected for these strains after boiling the bacterial suspensions at $100^{\circ} \mathrm{C}$ for $30 \mathrm{~min}$.

With the microplate technique described by

\section{References}

1. Crewe-Brown HH, Greeff AS, Fripp PJ. Aetiology of summer diarhoea at Ga-Rankuwa Hospital. In: Koornhof HJ (ed) Proceedings of the Symposium on Infections in Developing Countries. Parow, South African Medical Research Council. 1989: 232-233.

2. Butzler J-P, Glupczynski Y, Goossens H. Campylobacter and Helicobacter infections. Curr Opinion Infect Dis 1992; 5: 80-87.

3. Olusanya O, Adebayo JO, Williams B. Campylobacter jejuni as a bacterial cause of diarrhoea in Ile-Ife, Nigeria. $J$ Hyg 1983; 91 : 77-80.

4. Arimi SM, Park RWA, Fricker CR. Study of haemolytic activity of some Campylobacter spp. on blood agar plates. J Appl Bacteriol 1990; 69: 384-389.

5. Fricker CR, Alemohammad MM, Spencer S, Park RWA. The application of new and established tests to characterise unusual campylobacters isolated from men, animals and the environment. In: Pearson AD, Skirrow MB, Lior H, Rowe B (eds) Campylobacter III. London, Public Health Laboratory Service. 1985: 224-225.

6. Walker RI, Caldwell MB, Lee EC, Guerry P, Trust TJ, RuizPalacios GM. Pathophysiology of Campylobacter enteritis. Microbiol Rev 1986; 50: 81-94.
Dominguez-Rodriguez et al. ${ }^{11}$ for Listeria. monocytogenes, we were able to identify and quantitate the haemolytic activity in $94 \%$ of the campylobacters tested. This method is simple, distinguishes reliably between haemolytic and non-haemolytic isolates and should be the method of choice, since the agarose technique demonstrated haemolytic activity in only $56 \%$ of the isolates. In this study, the haemolytic activity of campylobacters as determined in the microplate assay was low in titre, ranging from 1 to 64 .

The detection of haemolytic activity in the majority of campylobacters examined suggests that this cellassociated activity could be a potential virulence factor contributing to campylobacter gastroenteritis. The production of haemolysin is a mechanism for microbes to obtain iron for bacterial growth and the expression of virulence factors. ${ }^{14}$ Iron overloading has been shown to increase the virulence of campylobacters, ${ }^{15,16}$ which also provides evidence for the importance of iron sequestration in campylobacter infections.

It is interesting to note that Shigella spp.-invasive enteropathogens - are classified as non-haemolytic, but were shown to lyse sheep erythrocytes when in close contact with them. ${ }^{17,18}$ The contact haemolytic activity of Shigella spp. was reported to play a role in the lysis of the phagocytic vacuole for the release of virulent shigellae into the host cytoplasm, where replication occurs. The invasive phenotype of shigellae is reported not to be differentiated through this haemolytic activity. ${ }^{19,20}$ All invasive Campylobacter isolates except four (three invasive, one non-invasive) detected in the gentamicin HEp-2 cell invasion assay were haemolytic (Tay et al., unpublished observations). Whether the same invasive mechanism plays a role in the campylobacters as in Shigella spp. needs further investigation.

This work forms part of the M.Med. Sci. thesis of S.T.T. and was supported by the University of Malaya and the Ministry of Science, Technology and Environment, Malaysia (R\&D) grant \# \# $3 / 077 / 01$

7. Korolik V, Coloe PJ, Krishnapillai V. A specific DNA probe for the identification of Campylobacter jejuni. J Gen Microbiol 1988; 134 : 521-529.

8. Lior H. New, extended biotyping scheme for Campylobacter jejuni, Campylobacter coli, and "Campylobacter laridis." J Clin Microbiol 1984; 20: 636-640.

9. Clarke PH. Hydrogen sulphide production by bacteria. J Gen Microbiol 1953; 8: 397.

10. Benjamin J, Leaper S, Owen RJ, Skirrow MB. Description of Campylobacter laridis, a new species comprising the nalidixic acid resistant thermophilic Campylobacter (NARTC) group. Curr Microbiol 1983; 8: 231-238.

11. Dominguez Rodriguez L, Vazquez Boland JA, Fernandez Garayzabal JF et al. Microplate technique to determine haemolytic activity for routine typing of Listeria strains. $J$ Clin Microbiol 1986; 24: 99-103.

12. Short EC, Kurtz H. Properties of the hemolytic activities of Escherichia coli. Infect Immun 1971; 3: 678-687.

13. Sakazaki R, Tamura $\mathrm{K}$, Murase $\mathrm{M}$. Determination of the hemolytic activity of Vibrio cholerae. Jpn J Med Sci Biol 1971; 24: 83-91.

14. Miyamoto Y, Kato T, Obara Y, Akiyama S, Takizawa T, Yamai S. In vitro hemolytic characteristic of Vibrio parahaemolyticus: its close correlation with human pathogenicity. $J$ Bacteriol 1969; 100 : 1147-1149. 
15. Kazmi SU, Roberson BS, Stern NJ. Animal-passed, virulenceenhanced Campylobacter jejuni causes enteritis in neonatal mice. Curr Microbiol 1984; 11: 150-164.

16. Stanfield JT, McCardell BA, Madden JM. Campylobacter diarrhea in an adult mouse model. Microbl Pathog $1987 ; 3$ : 155-165.

17. Clerc P, Baudry B, Sansonetti PJ. Plasmid-mediated contact haemolytic activity in Shigella species: correlation with penetration into HeLa cells. Ann Inst Pasteur Microbiol 1986; 137A: 267-278.

18. Sansonetti PJ, Ryter A, Clerc P, Maurelli AT, Mournier J. Multiplication of Shigella flexneri within HeLa cells: lysis of the phagocytic vacuole and plasmid-mediated contact hemolysis. Infect Immun 1986; 51: 461-469.

19. Baudry B, Maurelli AT, Clerc P, Sadoff JC, Sansonetti PJ. Localization of plasmid loci necessary for the entry of Shigella flexneri into HeLa cells, and characterisation of one locus encoding four immunogenic peptides. $J$ Gen Microbiol 1987; 133: 3403-3413.

20. Kato J-I, Ito K-I, Nakamura A, Watanabe H. Cloning of regions required for contact hemolysis and entry into LLCMK2 cells from Shigella sonnei form 1 plasmid: virF is a positive regulator gene for these phenotypes. Infect Immun 1989; 57: 1391-1398. 